\title{
DETERMINATION OF DIELECTRIC STRESS OF MEdiUM Voltage CABLES BY MATHEMATICAL MODELS IN EMTP-ATP AND ANSYS
}

\author{
MISAK, S. \& SNUPAREK, P.
}

Abstract: Cables lines are important components of the reliability system at medium voltage levels. The insulating system of the cable line is stressed by some degrading factors during its operating mode. A temperature, a kind and amplitude of voltage, humidity and mechanical stress are main degrading factors. The dielectric stress of medium voltage cable line 6AYKCY $3 \times 70 / 16$ is determined by EMTP-ATP and ANSYS program for running state and 1phase arc-earth fault. The electric intensity distribution is simulated by ANSYS program in dielectric of cable in the concrete. Results are used as enters dates for ANSYS program from simulations in EMTP-ATP. Some results from mathematical modelling are introduced within this paper

Key words: Diagnostic, Dielectric, EMTP-ATP, ANSYS, Cable
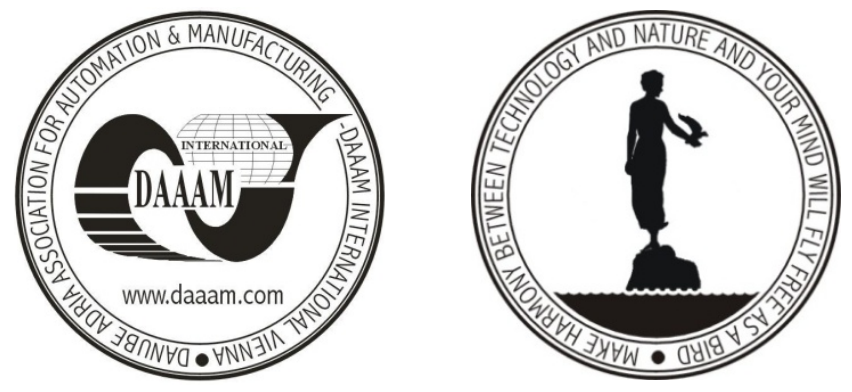

Authors' data: Dr. Misak, S[tanislav]*; Snuparek, P[etr]**, *Technical University of Ostrava, VSB-TU Ostrava,FEI,K453, 70833, Ostrava, CZ, ** VSB-TU Ostrava, Vrbátky 76, 79813, Prostějov,CZ, stanislav.misak@seznam.cz, petr.snuparek@centrum.cz

This Publication has to be referred as: Misak, S[tanislav] \& Snuparek, P[etr] (2008). Determination of Dielectric Stress of Medium Voltage Cables by Mathematical Models in Emtp-Atp and Ansys, Chapter 42 in DAAAM International Scientific Book 2008, pp. 499-508, B. Katalinic (Ed.), Published by DAAAM International, ISBN 978-3-901509-66-7, ISSN 1726-9687, Vienna, Austria DOI: $10.2507 /$ daaam.scibook.2008.42 